\title{
TALAJCSAPDÁS ARACHNOLÓGIAI VIZSGÁLAT AZ ÁSOTTHALMI TANULMÁNYI-ERDŐBEN
}

\author{
Bali László ${ }^{1}$, Szinetár Csaba ${ }^{2}$, Andrési Dániel ${ }^{1,3}$, Tuba Katalin ${ }^{1}$ és Kálmán Kristóf ${ }^{1}$ \\ 1 Soproni Egyetem, Erdömérnöki Kar \\ 2 ELTE, TTK SEK Biológia Tanszék \\ 3 KEFAG Kiskunsági Erdészeti és Faipari Zrt.
}

\begin{abstract}
Kivonat
Vizsgálatunk során az ásotthalmi Tanulmányi-erdő talajfelszíni pókfaunáját mértük fel talajcsapdázással a 2014-es évben, március és október hónapok között. A vizsgálati terület három, egymástól jól elkülöníthető élöhelyéről gyüjtöttünk adatokat: 2-2 mintavétel tölgyesben, fenyvesben és tisztáson. A Tanulmányi-erdő vizsgált részleteinek talajfelszínen élő pókközösséget hasonlítottuk össze a fajkompozíciók, azok természetessége és néhány további közösség-ökológiai mutató alapján. A párhuzamos felmérések adatai alapján megállapítottuk, hogy a három élettér mind egyedszám, mind fajszám, mind diverzitás alapján egyértelműen eltér egymástól. A terület természetessége általánosan jónak mondható, ez különösen a tisztások esetében jellemző. Az erdőkhöz és erdőszegélyekhez kötődő fajok a fás élőhelyeken, míg a nyilt és száraz élöhelyeket kedvelők a tisztásokon voltak nagyobb arányban jelen.
\end{abstract}

Kulcsszavak: talajcsapdázás, talajfelszíni pók közösségek, Araneae, fenyves, tölgyes, tisztás.

\section{PITFALL TRAPPING ARACHNOLOGICAL SURVEY IN THE EDUCATIONAL FOREST OF ÁSOTTHALOM}

\begin{abstract}
During our research we surveyed the ground-dwelling spider fauna of the Educational Forest of Ásotthalom by piffall trapping. The research was conducted from March to October in 2014. We collected data from three different habitats with 2 sampling sites for each: oak forest, pine forest and clearing. Our goals were to assess the ground-dwelling spider assemblages of the habitats, compare their spider fauna, determine their naturalness and examine their basic community-ecological indices. According to our data, species- and specimen number and diversity can separate the three habitats. The originality of the survey area is good, especially the clearings'. The forest and forest-edge inhabiting species were more abundant in the woodlands, while the open and dry conditions preferring species were more frequent in the clearings.
\end{abstract}

Keywords: pitfall trapping, ground-dwelling spider assemblages, Araneae, pine forest, oak forest, clearing. 


\section{BEVEZETÉS}

Ásotthalom a Nagyalföld erdészeti tájon belül a Duna-Tisza közi hátság tájrészlet déli részén fekszik (Halász 2006). A település környékén elterülő erdők területe közel 5000 hektár. A vizsgálatunk tárgyát képező, a Bedő Albert Erdészeti Szakképző Iskola és Kollégium által kezelt Tanulmányi erdő területe 441 hektár. Vizsgálatunk során az erdő hat részletének talajfelszíni pókfaunáját mértük fel 2014-ben. Összesen három, egymástól jól elkülöníthető élöhelytípusból gyüjtöttünk adatokat, két tölgyes, két kultúrfenyves és két tisztás területéröl. A vizsgált erdő területén ezt megelőzően arachnológiai vizsgálat még nem, de például futóbogarakkal foglalkozó (Andrési et al 2015, Kálmán 2016) már zajlott.

Az Alföld erdei arachnológiai szempontból meglehetősen hiányosan kutatottak. Az itt végzett kutatások közül Gallé \& Torma (2009), Szinetár et al (2011), valamint Gallé et al (2014) munkáit emelhetjük ki, amelyek részben honos pusztai tölgyesekkel, valamint ültetett nyárasokkal foglalkoztak.

Jelen vizsgálat céljai voltak a Tanulmányi erdő talajfelszíni pókközösségeinek vizsgálata, valamint a három eltérő élőhely összehasonlitása a pókközösségek természetességi- és néhány további közösség-ökológiai mutatója segítségével.

Választásunk azért erre az ízeltlábú csoportra esett, mivel erdészeti vonatkozásban viszonylag kevésbé kutatottak. Holott a pókok, mint generalista ragadozó szervezetek, az erdei ökoszisztémáknak fontos részét képezik (Wise 1993); valamint, mint indikátor szervezetek, érzékenyen reagálnak a környezeti tényezők és a vegetáció strukturális változásaira (Horváth et al 2009, Horváth 2012, Maelfaitl \& Hendrickx 1997), továbbá jól ismételhetően, költséghatékonyan gyüjthetök, ökológiai szempontból jól értelmezhető az előfordulásuk, és egyszerüen vizsgálhatók (Ferris et al 2000).

\section{ANYAG ÉS MÓDSZER}

Az adatgyüjtéshez védőtetővel ellátott Barber-féle duplaedényes talajcsapdákat használtunk (Barber 1931), amelyekbe ölöfolyadékként $2 \mathrm{dl}, 10$ ff\%-os ecetsavat töltöttünk. A csapdák kihelyezése 2014.03.29-én történt. A hat mintaterületen (két tölgyes, két kultúrfenyves, két tisztás) (1. ábra), háromszoros ismétléssel, összesen 18 csapdát üzemeltettünk. A vizsgált erdörészletek összterülete 22,43 ha volt (1. táblázat).

Az alkalmazott gyüjtési módszer a külföldi és a hazai gyakorlatban egyaránt elterjedt a talajfelszínen élő pókok vizsgálatában (Woodcock 2005, Kádár \& Samu 2006). A csapdák ürítése 2014.04.19.-2014.10.27. között háromheti rendszerességgel, összesen 10 alkalommal történt, a csapdák így összesen 212 napig müködtek. A begyüjtött mintákat laboratóriumi körülmények között válogattuk szét és a meghatározásig 70\%-os etil-alkoholban tároltuk. 
1. táblázat: $A$ vizsgált területek jellemzői.

Table 1: The attributes of the survey areas.

\begin{tabular}{|c|c|c|c|c|}
\hline Részlet neve & Jelölés & Élöhely jellege & Terület (ha) & Kor \\
\hline 300/TI2 & R1 & Tisztás (nyilt homoki gyep) & 0,57 & - \\
\hline 302/A & F1 & Erdei- és feketefenyves & 11,26 & 38 \\
\hline 305/F & T1 & Kocsányos tölgyes & 0,76 & 118 \\
\hline 308/E & T2 & Szlavón tölgyes & 4,05 & 106 \\
\hline 310/H & F2 & Erdei- és feketefenyves & 3,81 & 46 \\
\hline $314 / T I 3$ & R2 & Tisztás (zárt homoki gyep) & 1,98 & - \\
\hline
\end{tabular}

A pókfajok gyakoriságának jellemzéséhez Palmgren \& Lönnqvist (1974), valamint Szinetár et al (2006) által alkalmazott dominancia kategóriákat használtuk, melyek az alábbiak voltak: 0,2\%-ig ritka; 0,2-0,5\%: szórványos; 0,5-2\%: gyakori; 2-5\%: szubdomináns; $5 \%$ felett domináns; $10 \%$ feletti gyakoriság esetén pedig a szuperdomináns kategóriát alkalmaztuk.

Mivel a szuperdomináns és domináns fajok ökológiai igényei jól jellemzik az adott mintaterületeket, ezért ezeket a vonatkozó fejezetben röviden ismertettük, amihez Hänggi et al (1995), valamint Buchar \& Rủžička (2002) munkáit vettük alapul. A vizsgált szempontok az élőhely természetességi foka (természetes, természetközeli, bolygatott, mesterséges), az élőhely típusa (erdei, szegélyben élő, nyílt területen élö), a megvilágítottság (árnyékolt, részlegesen árnyékolt) és a humiditás (száraz, humid) voltak.

A pókközösségeket a fajdiverzitás (Shannon-Weaver diverzitási index (Shannon \& Weaver 1949)), valamint a kiegyenlítettség (ekvitabilitás) alapján is összehasonlítottuk. Utóbbi inkább a ritkább fajokra tekinthető érzékenynek. Az egyes csapdák és élőhelyrészek fajegyüttesei közötti hasonlóságok megállapításához (Bray-Curtis indexen alapuló (Bray \& Curtis 1957) ordinációs vizsgálatot végeztünk, aminek módszere nem-metrikus többdimenziós skálázás (Non-metric MDS) volt. Az egyes csapdák összehasonlítását elvégeztük még a Jaccard-féle fajazonossági index (Jaccard 1912) alapján is. A fajösszetétel-azonosság indexet az egyes mintaterületekre vetítve, az összehasonlított életterek teljes egyedszámának arányában, a Renkonen indexhez (Renkonen 1938) hasonlóan készítettük: az egyes mintaterületek az egyedszámokkal súlyozott fajkészletük szerint, páronként kerültek összehasonlításra, azon értékeket figyelembe véve, amelyek mindkét mintában megtalálhatóak, mégpedig a közös egyedszám függvényében. Elvégeztük a hat mintaterületet Rényi-féle diverzitásrendezést is (Rényi 1961). 


\section{TANULMÁNYI ERDÓ}

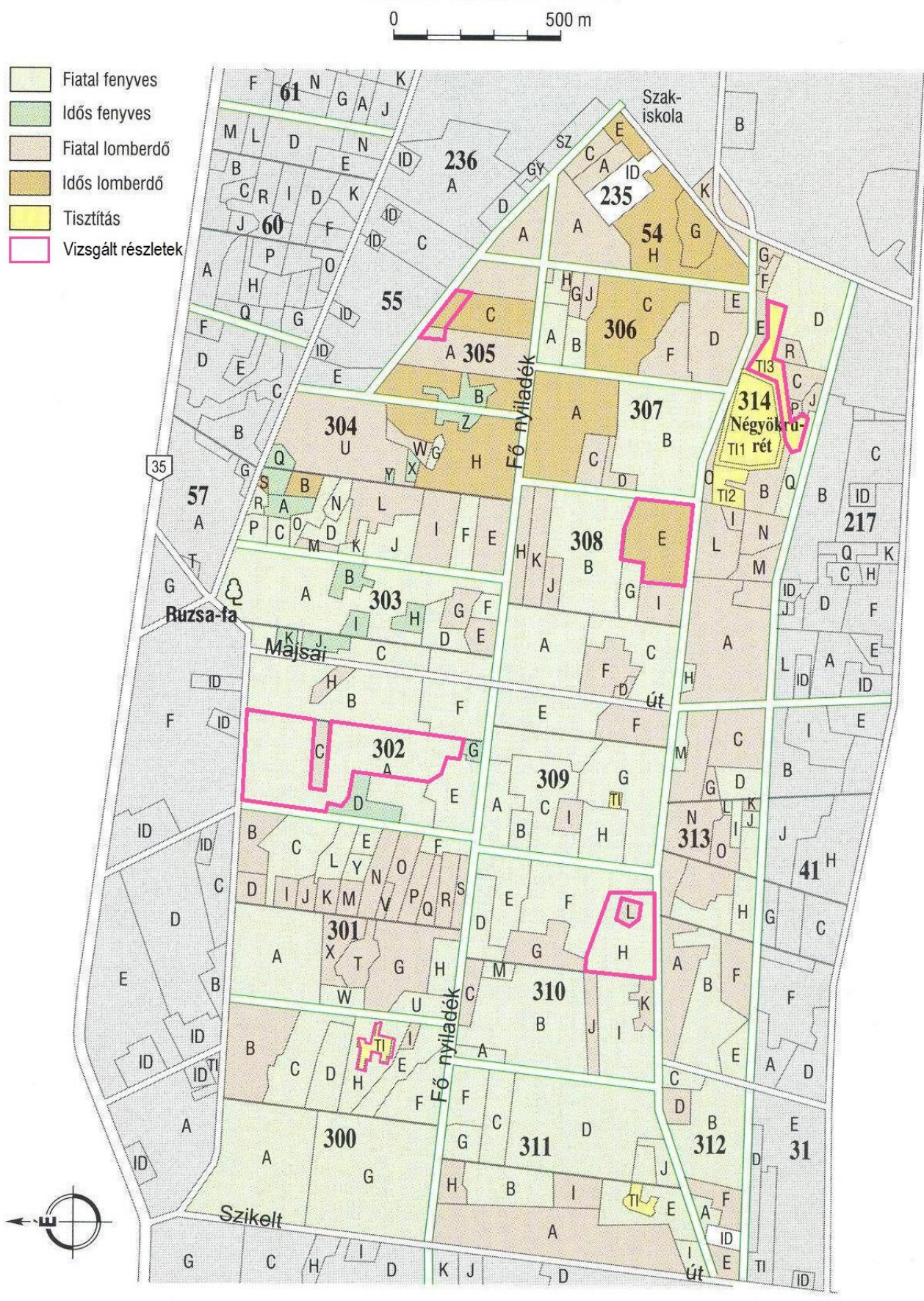

1. ábra: Az ásotthalmi Tanulmányi erdő a vizsgált részletekkel.

Figure 1: The Educational forest of Ásotthalom with the surveyed compartments (red). 


\section{EREDMÉNYEK ÉS MEGVITATÁSUK}

A vizsgálat során összesen 2943 pók került befogásra, amelyből 22 család 68 fajának 2030 egyedét sikerült faji szinten beazonositani. Az átlagos fogás 0,77 egyed/csapda/nap és 0,02 faj/csapda/nap volt. Ezen adatok alapján az ásotthalmi Tanulmányi erdő élöhelyeinek talajfelszíni pókközösségeinek fajszáma hasonló $(0,02 \mathrm{f} / \mathrm{cs} / \mathrm{n})$, egy nyugat-magyarországi cseresben tapasztalthoz. Az egyedszám a cseresben (Vép 32/D) 1,03 e/cs/n volt (Bali et al 2016a), ennél az értéknél a Tanulmányi erdö tölgyesei magasabbat (1,35 e/cs/n), a fenyvesek $(0,63 \mathrm{e} / \mathrm{cs} / \mathrm{n})$ és gyepterületek $(0,34 \mathrm{e} / \mathrm{cs} / \mathrm{n})$ pedig alacsonyabbat mutattak. A legtöbb egyedet (959) a T2, a legkevesebbet (184) pedig a R1 területen fogtuk. A vizsgált három élőhely talajfelszíni pókjainak abundanciája tehát jelentősen különbözik egymástól: a tölgyesekben az összes egyedszám közel $60 \%$-át, míg a fenyvesekben a teljes egyedszám $25 \%$-át, a gyepekben pedig mindössze $15 \%$-át fogtuk. A legmagasabb fajszámot (35) a R2, a legalacsonyabbat (21) pedig a T1 területen kaptuk (2. táblázat).

2. táblázat: Fogási eredmények ( $D$ - dominancia; kiemelve - az 5-nél nagyobb dominancia értékű fajok).

Table 2: The trapping results ( $D$ - dominance; bold - species with dominance values exceeding 5$)$.

\begin{tabular}{|l|c|c|c|c|c|c|c|c|c|}
\hline \multirow{2}{*}{ Taxon } & \multicolumn{3}{|c|}{ Tölgyes (T) } & \multicolumn{3}{c|}{ Fenyves (F) } & \multicolumn{3}{c|}{ Tisztás (R) } \\
\cline { 2 - 12 } & $\mathbf{1}$ & $\mathbf{2}$ & $\mathbf{D}$ & $\mathbf{1}$ & $\mathbf{2}$ & $\mathbf{D}$ & $\mathbf{1}$ & $\mathbf{2}$ & $\mathbf{D}$ \\
\hline Nemesiidae spp. juv. & - & - & - & - & - & - & 1 & 2 & - \\
\hline $\begin{array}{l}\text { Nemesia pannonica } \\
\text { Herman, 1879 }\end{array}$ & - & - & - & - & 1 & 0,13 & 6 & 13 & 4,41 \\
\hline $\begin{array}{l}\text { Harpactea rubicunda } \\
\text { (C. L. Koch, 1838) }\end{array}$ & 12 & 18 & 1,75 & - & 4 & 0,50 & - & - & - \\
\hline $\begin{array}{l}\text { Ero furcata } \\
\text { (Villers, 1789) }\end{array}$ & - & 2 & 0,12 & 2 & - & 0,25 & - & - & - \\
\hline $\begin{array}{l}\text { Eresus kollari } \\
\text { Rossi, 1846 }\end{array}$ & - & - & - & - & - & - & 1 & - & 0,23 \\
\hline $\begin{array}{l}\text { Cercidia prominens } \\
\text { (Westring, 1851) }\end{array}$ & - & 2 & 0,12 & - & - & - & - & - & - \\
\hline Lyniphiidae spp. juv. & 4 & 11 & - & 24 & 12 & - & 6 & 2 & - \\
\hline $\begin{array}{l}\text { Bathyphantes gracilis } \\
\text { (Blackwall, 1841) }\end{array}$ & 1 & - & 0,06 & - & - & - & - & - & - \\
\hline $\begin{array}{l}\text { Canariphantes nanus } \\
\text { (Kulczyński, 1898) }\end{array}$ & 30 & 72 & $\mathbf{5 , 9 5}$ & 51 & 35 & 10,79 & 2 & 5 & 1,62 \\
\hline $\begin{array}{l}\text { Diplostyla concolor } \\
\text { (Wider, 1834) }\end{array}$ & - & 1 & 0,06 & - & - & - & - & - & - \\
\hline
\end{tabular}




\begin{tabular}{|l|c|c|c|c|c|c|c|c|c|}
\hline \multirow{2}{*}{ Taxon } & \multicolumn{3}{|c|}{ Tölgyes (T) } & \multicolumn{3}{c|}{ Fenyves (F) } & \multicolumn{3}{c|}{ Tisztás (R) } \\
\cline { 2 - 10 } & $\mathbf{1}$ & $\mathbf{2}$ & $\mathbf{D}$ & $\mathbf{1}$ & $\mathbf{2}$ & $\mathbf{D}$ & $\mathbf{1}$ & $\mathbf{2}$ & $\mathbf{D}$ \\
\hline $\begin{array}{l}\text { Tenuiphantes flavipes } \\
\text { (Blackwall, 1854) }\end{array}$ & 4 & 80 & 4,90 & - & - & - & - & 1 & 0,23 \\
\hline $\begin{array}{l}\text { Panamomops mengei } \\
\text { Simon, 1926 }\end{array}$ & - & - & - & 1 & 1 & 0,25 & - & - & - \\
\hline $\begin{array}{l}\text { Pelecopsis radicicola } \\
\text { (L. Koch, 1872) }\end{array}$ & - & - & - & - & - & - & 1 & - & 0,23 \\
\hline $\begin{array}{l}\text { Sintula spiniger } \\
\text { (Balogh, 1935) }\end{array}$ & - & - & - & 10 & 1 & 1,38 & 15 & 4 & 4,41 \\
\hline $\begin{array}{l}\text { Trichoncus affinis } \\
\text { (Kulczyński, 1894) }\end{array}$ & - & - & - & - & - & - & - & 3 & 0,70 \\
\hline $\begin{array}{l}\text { Trichopterna cito } \\
\text { (O. P.-Cambridge, 1872) }\end{array}$ & - & - & - & - & - & - & 1 & - & 0,23 \\
\hline $\begin{array}{l}\text { Walckenaeria obusta } \\
\text { Blackwall, 1836 }\end{array}$ & - & - & - & - & - & - & - & 1 & 0,23 \\
\hline Tetraganthidae spp. juv. & - & - & - & 1 & - & - & - & - & - \\
\hline $\begin{array}{l}\text { Metellina segmentata } \\
\text { (Clerck, 1757) }\end{array}$ & - & 1 & 0,06 & - & - & - & - & - & - \\
\hline $\begin{array}{l}\text { Asagena phalerata } \\
\text { (Panzer, 1801) }\end{array}$ & - & 7 & 0,41 & 1 & - & 0,13 & - & - & - \\
\hline $\begin{array}{l}\text {-Steatoda albomaculata } \\
\text { (De Geer, 1778) }\end{array}$ & - & - & - & 1 & - & 0,13 & 1 & - & 0,23 \\
\hline $\begin{array}{l}\text { Enoplognatha thoracica } \\
\text { (Hahn, 1833) }\end{array}$ & - & 1 & 0,06 & 2 & - & 0,25 & - & 1 & 0,23 \\
\hline $\begin{array}{l}\text { Euryopis quinqueguttata } \\
\text { Thorell, 1875 }\end{array}$ & - & - & - & - & - & - & 1 & - & 0,23 \\
\hline $\begin{array}{l}\text { Episinus trunctatus } \\
\text { Latreille, 1809 }\end{array}$ & 1 & 1 & 0,12 & 4 & 14 & 2,26 & - & - & - \\
\hline Lycosidae spp. juv. & 249 & 85 & - & 130 & 100 & - & 68 & 38 & - \\
\hline $\begin{array}{l}\text { Alopecosa farinosa } \\
\text { (Herman, 1879) }\end{array}$ & - & - & - & - & - & - & - & 3 & 0,70 \\
\hline $\begin{array}{l}\text { Alopecosa cuneata } \\
\text { (Cleck, 1757) }\end{array}$ & - & - & - & - & - & - & 2 & 12 & 3,25 \\
\hline $\begin{array}{l}\text { Alopecosa mariae } \\
\text { (Dahl, 1908) }\end{array}$ & - & 1 & 0,06 & - & - & - & 1 & 6 & 1,62 \\
\hline $\begin{array}{l}\text { Alopecosa sulzeri } \\
\text { (Pavesi, 1873) }\end{array}$ & - & $-0,06$ & 6 & 18 & 3,01 & 11 & 4 & 3,48 \\
\hline
\end{tabular}




\begin{tabular}{|c|c|c|c|c|c|c|c|c|c|}
\hline \multirow{2}{*}{ Taxon } & \multicolumn{3}{|c|}{ Tölgyes (T) } & \multicolumn{3}{|c|}{ Fenyves (F) } & \multicolumn{3}{|c|}{ Tisztás (R) } \\
\hline & 1 & 2 & D & 1 & 2 & D & 1 & 2 & D \\
\hline $\begin{array}{l}\text { Arctosa figurata } \\
\text { (Simon, 1876) }\end{array}$ & - & - & - & 1 & 1 & 0,25 & - & 2 & 0,46 \\
\hline $\begin{array}{l}\text { Alopecossa trabalis } \\
\text { (Clerck, 1757) }\end{array}$ & - & - & - & - & - & - & - & 1 & 0,23 \\
\hline $\begin{array}{l}\text { Arctosa lutetiana } \\
\text { (Simon, 1876) }\end{array}$ & 27 & 57 & 4,90 & 8 & 15 & 2,89 & 3 & - & 0,70 \\
\hline $\begin{array}{l}\text { Trochosa terricola } \\
\text { Thorell, } 1856\end{array}$ & 3 & 10 & 0,76 & 36 & 18 & 6,78 & - & 2 & 0,46 \\
\hline $\begin{array}{l}\text { Pardosa alacris } \\
\text { (C. L. Koch, 1833) }\end{array}$ & 318 & 389 & 41,22 & 66 & 44 & 13,80 & 2 & 2 & 0,93 \\
\hline $\begin{array}{l}\text { Xerolycosa miniata } \\
\text { (C. L. Koch, 1834) }\end{array}$ & - & - & - & . & - & & - & 1 & 0,23 \\
\hline $\begin{array}{l}\text { Pisaura mirabilis } \\
\text { (Clerck, 1757) }\end{array}$ & - & - & - & 1 & - & 0,13 & - & 1 & 0,23 \\
\hline Miturgidae spp. juv. & - & - & - & - & - & - & 1 & - & - \\
\hline $\begin{array}{l}\text { Zora pardalis } \\
\text { Simon, } 1878\end{array}$ & - & - & - & - & - & - & 1 & 1 & 0,46 \\
\hline $\begin{array}{l}\text { Zora spinimana } \\
\text { (Sundevall, 1833) }\end{array}$ & 5 & - & 0,29 & - & - & - & - & - & - \\
\hline $\begin{array}{l}\text { Cryphoeca silvicola } \\
\text { (C. L. Koch, 1834) }\end{array}$ & - & - & - & 1 & - & 0,13 & - & - & - \\
\hline $\begin{array}{l}\text { Zodarion germanicum } \\
\text { (C. L. Koch, 1837) }\end{array}$ & 7 & 21 & 1,63 & 1 & 1 & 0,25 & - & 14 & 3,25 \\
\hline $\begin{array}{l}\text { Clubonia comta } \\
\text { C. L. Koch, } 1839\end{array}$ & 2 & - & 0,12 & 1 & - & 0,13 & - & - & - \\
\hline $\begin{array}{l}\text { Cheiracanthium elegans } \\
\text { Thorell, } 1875\end{array}$ & - & 1 & 0,06 & - & - & - & - & - & - \\
\hline $\begin{array}{l}\text { Titanocea schineri } \\
\text { L. Koch, } 1872\end{array}$ & 1 & 3 & 0,23 & 2 & 9 & 1,38 & 2 & - & 0,46 \\
\hline Gnaphosidae spp. juv. & 16 & 24 & - & 13 & 43 & - & 3 & 27 & - \\
\hline $\begin{array}{l}\text { Berlandina cinerea } \\
\text { (Menge, 1872) }\end{array}$ & - & - & - & - & - & - & 2 & - & 0,46 \\
\hline $\begin{array}{l}\text { Drassylus praeficus } \\
\text { (L. Koch, 1866) }\end{array}$ & - & - & - & - & - & - & 2 & 1 & 0,70 \\
\hline $\begin{array}{l}\text { Drassylus villicus } \\
\text { (Thorell, 1875) }\end{array}$ & 18 & 44 & 3,62 & 2 & 11 & 1,63 & 3 & 2 & 1,16 \\
\hline
\end{tabular}




\begin{tabular}{|c|c|c|c|c|c|c|c|c|c|}
\hline \multirow{2}{*}{ Taxon } & \multicolumn{3}{|c|}{ Tölgyes (T) } & \multicolumn{3}{|c|}{ Fenyves (F) } & \multicolumn{3}{|c|}{ Tisztás (R) } \\
\hline & 1 & 2 & D & 1 & 2 & D & 1 & 2 & D \\
\hline $\begin{array}{l}\text { Gnaphosa mongolica } \\
\text { Simon, } 1895\end{array}$ & - & - & - & - & - & - & 1 & - & 0,23 \\
\hline $\begin{array}{l}\text { Haplodrassus signifer } \\
\text { (C. L. Koch, 1839) }\end{array}$ & - & 1 & 0,06 & - & - & - & 1 & 6 & 1,62 \\
\hline $\begin{array}{l}\text { Haplodrassus silvestris } \\
\text { (Blackwall, 1833) }\end{array}$ & - & 4 & 0,23 & - & - & - & - & - & - \\
\hline $\begin{array}{l}\text { Micaria dives } \\
\text { (Lucas, 1846) }\end{array}$ & - & - & - & - & - & - & - & 1 & 0,23 \\
\hline $\begin{array}{l}\text { Nomisia exoranta } \\
\text { (C. L. Koch, 1839) }\end{array}$ & - & - & - & - & - & - & - & 1 & 0,23 \\
\hline $\begin{array}{l}\text { Trachyzelotes pedestris } \\
\text { (C. L. Koch, 1837) }\end{array}$ & 2 & 8 & 0,58 & - & 4 & 0,50 & 1 & - & 0,23 \\
\hline $\begin{array}{l}\text { Zelotes apricorum } \\
\text { (L. Koch, 1876) }\end{array}$ & 11 & 28 & 2,27 & 27 & 28 & 6,90 & 1 & 1 & 0,46 \\
\hline $\begin{array}{l}\text { Zelotes electus } \\
\text { (C. L. Koch, 1839) }\end{array}$ & - & 1 & 0,06 & 1 & - & 0,13 & 11 & 22 & 7,66 \\
\hline $\begin{array}{l}\text { Zelotes longipes } \\
\text { (L. Koch, 1866) }\end{array}$ & - & - & - & - & - & - & - & 2 & 0,46 \\
\hline Philodromidae spp. juv. & 1 & - & - & - & 2 & - & 1 & 3 & - \\
\hline $\begin{array}{l}\text { Philodromus dispar } \\
\text { Walckenaer, } 1826 \\
\end{array}$ & - & 1 & 0,06 & - & - & - & - & - & - \\
\hline $\begin{array}{l}\text { Philodromus fuscomargi- } \\
\text { natus } \\
\text { (De Geer, 1778) }\end{array}$ & & & - & 1 & - & 0,13 & ( & & \\
\hline $\begin{array}{l}\text { Thanatus arenarius } \\
\text { L. Koch, } 1872\end{array}$ & - & - & - & - & 1 & 0,13 & 1 & 24 & 5,80 \\
\hline Thomisidae spp. juv. & 3 & 3 & - & 2 & 3 & - & 3 & 2 & - \\
\hline $\begin{array}{l}\text { Ozyptila particola } \\
\text { (C. L. Koch, 1837) }\end{array}$ & 5 & 36 & 2,39 & - & - & - & - & 1 & 0,23 \\
\hline $\begin{array}{l}\text { Xysticus kochi } \\
\text { Thorell, } 1872\end{array}$ & 1 & - & 0,06 & - & - & - & 16 & 11 & 6,26 \\
\hline $\begin{array}{l}\text { Xysticus lanio } \\
\text { C. L. Koch, } 1835\end{array}$ & - & 1 & 0,06 & - & - & - & - & - & - \\
\hline $\begin{array}{l}\text { Xysticus luctator } \\
\text { L. Koch, } 1870\end{array}$ & 23 & 38 & 3,56 & 2 & 20 & 2,76 & - & - & - \\
\hline $\begin{array}{l}\text { Xysticus robostus } \\
\text { (Hahn, 1832) }\end{array}$ & - & 1 & 0,06 & - & 1 & 0,13 & - & 8 & 1,86 \\
\hline
\end{tabular}




\begin{tabular}{|l|c|c|c|c|c|c|c|c|c|}
\hline \multirow{2}{*}{ Taxon } & \multicolumn{3}{|c|}{ Tölgyes (T) } & \multicolumn{3}{c|}{ Fenyves (F) } & \multicolumn{3}{c|}{ Tisztás (R) } \\
\cline { 2 - 10 } & $\mathbf{1}$ & $\mathbf{2}$ & $\mathbf{D}$ & $\mathbf{1}$ & $\mathbf{2}$ & $\mathbf{D}$ & $\mathbf{1}$ & $\mathbf{2}$ & $\mathbf{D}$ \\
\hline Salticidae spp. juv. & - & 1 & - & - & 1 & - & 6 & 5 & - \\
\hline $\begin{array}{l}\text { Aelurillus v-insignitus } \\
\text { (Clerck, 1757) }\end{array}$ & - & - & - & - & - & - & 1 & 1 & 0,46 \\
\hline $\begin{array}{l}\text { Ballus chalybeius } \\
\text { (Walckenaer, 1802) }\end{array}$ & 1 & 2 & 0,17 & - & - & - & - & - & - \\
\hline $\begin{array}{l}\text { Euophrys frontalis } \\
\text { (Walckenaer, 1802) }\end{array}$ & - & - & - & - & 1 & 0,13 & 2 & - & 0,46 \\
\hline $\begin{array}{l}\text { Heliophanus flavipes } \\
\text { (Hahn, 1832) }\end{array}$ & - & - & - & - & - & - & - & 1 & 0,23 \\
\hline $\begin{array}{l}\text { Marpissa muscosa } \\
\text { (Clerck, 1757) }\end{array}$ & - & - & - & - & 1 & 0,13 & - & - & - \\
\hline $\begin{array}{l}\text { Evarcha falcata } \\
\text { (Clerck, 1757) }\end{array}$ & 1 & - & 0,06 & - & 3 & 0,38 & 1 & - & 0,23 \\
\hline $\begin{array}{l}\text { Phlegra fasciata } \\
\text { (Hahn, 1826) }\end{array}$ & - & - & - & - & - & - & - & 4 & 0,93 \\
\hline $\begin{array}{l}\text { Phrurolithus minimus } \\
\text { C. L. Koch, 1839 }\end{array}$ & 2 & - & 0,12 & 1 & 1 & 0,25 & 1 & 1 & 0,46 \\
\hline $\begin{array}{l}\text { Agroeca cuprea } \\
\text { Menge, 1873 }\end{array}$ & - & - & - & - & 2 & 0,25 & - & - & - \\
\hline Juvenilis & 8 & 1 & - & 1 & 1 & - & - & 4 & - \\
\hline Nem meghatározható & - & 1 & - & - & - & - & 1 & - & - \\
\hline Összes egyedszám & $\mathbf{7 5 6}$ & $\mathbf{9 5 9}$ & $\mathbf{1 7 1 5}$ & $\mathbf{4 0 0}$ & $\mathbf{3 9 7}$ & $\mathbf{7 9 7}$ & $\mathbf{1 8 4}$ & $\mathbf{2 4 7}$ & $\mathbf{4 3 1}$ \\
\hline Egyedszám/csapda/nap & $\mathbf{1 , 1 9}$ & $\mathbf{1 , 5 1}$ & $\mathbf{1 , 3 5}$ & $\mathbf{0 , 6 3}$ & $\mathbf{0 , 6 2}$ & $\mathbf{0 , 6 3}$ & $\mathbf{0 , 2 9}$ & $\mathbf{0 , 3 9}$ & $\mathbf{0 , 3 4}$ \\
\hline Összes fajszám & $\mathbf{2 1}$ & $\mathbf{3 0}$ & $\mathbf{3 6}$ & $\mathbf{2 5}$ & $\mathbf{2 3}$ & $\mathbf{3 3}$ & $\mathbf{3 0}$ & $\mathbf{3 5}$ & $\mathbf{4 7}$ \\
\hline Fajszám/csapda/nap & $\mathbf{0 , 0 3}$ & $\mathbf{0 , 0 5}$ & $\mathbf{0 , 0 3}$ & $\mathbf{0 , 0 4}$ & $\mathbf{0 , 0 4}$ & $\mathbf{0 , 0 3}$ & $\mathbf{0 , 0 5}$ & $\mathbf{0 , 0 6}$ & $\mathbf{0 , 0 4}$ \\
\hline
\end{tabular}

A gyüjtött anyagban a legfajgazdagabbnak a kövipókok (Gnaphosidae) családja bizonyult, 12 fajjal. A legtöbb egyed (1741), a farkaspókok (Lycosidae) családjából került elö. A család nagy egyedszáma többek között annak köszönhető, hogy ezek az állatok egy nap alatt több tíz méteres távolságot tudnak megtenni (Greenstone 1979, Kiss \& Samu 2000), így rövid idő alatt képesek a habitatok, mikrohabitatok között vándorolni. Tehetik ezt táplálékszerzés céljából, vagy azért, hogy az abiotikus tényezőkben bekövetkező változásokat kompenzálják. 
A legnagyobb egyedszámmal a Pardosa alacris (C. L. Koch, 1833) került elö, összesen 821 egyeddel. Ez a faj szuperdomináns volt mind a tölgyes, mind a fenyves mintaterületeken. A kimutatott magas egyedszám egybevág azzal, hogy ez a faj a magyarországi erdők egyik leggyakoribb pókfaja. Az erdőktől csak kissé távolodik el (Loksa 1972), a talajfelszínen lévő avar és részleges árnyékolás szükséges számára. Kerüli a szélsőségesen száraz, meleg és nyílt élőhelyeket (Szinetár 2006). A mérsékelten száraz és részlegesen nyílt erdőket és erdőszegélyeket kedveli.

A Canariphantes nanus (Kulczyński, 1898) a fenyves területeken szuperdomináns, a tölgyesekben pedig domináns volt. Ezzel egybevágnak korábbi adatai, miszerint föként száraz, nyilt élöhelyekhez, valamint fenyő- és tölgyerdökhöz kötődik (Gnelista 2008).

A Trochosa terricola Thorell, 1856 a fenyvesekben volt domináns. Ez faj füves területekre, lomb- és nyitvatermő erdőkre, valamint erdőszegélyekre jellemző. A mi vizsgálatunk is hasonló eredményeket hozott. Elmondható még róla, hogy a valamelyest humid körülményeket kedveli. Egy korábbi felmérésünkben (Bali et al 2016a) és jelen vizsgálatunkban is jellemzően együtt fordult elő a $P$. alacris fajjal.

A Zelotes apricorum (L. Koch, 1876) szintén a fenyvesekben volt domináns. A megvilágítottság és humiditás szempontjából tágtűrésűnek mondható.

A Zelotes electus (C. L. Koch, 1839) a tisztások esetében volt domináns. Száraz, nyilt és füves területekhez köthetö, amit adataink megerösítenek.

A Thanatus arenarius L. Koch, 1872 is a tisztásokon volt domináns. Ez a faj szintén száraz és nyílt élöhelyekhez köthetö.

Az előző fajhoz hasonlóan a tisztásokon volt domináns a Xysticus kochi Thorell, 1872. Ez a faj is száraz és nyilt élőhelyekhez, jellemzően rétekhez és egyéb füves területekhez köthetö.

Faunisztikai és természetvédelmi szempontból is kiemelendő két védett faj, a magyar aknászpók (Nemesia pannonica Herman, 1879) és a skarlát bikapók (Eresus kollari Rossi, 1846) jelenléte. Mindkét faj ritka, értékes és védett tagja a magyarországi pókfaunának (100/2012. (IX. 28.) VM rendelet). A magyar aknászpók fenyőállomány alól való előkerülése valószínüleg annak gyep eredetével magyarázható (Bali et al 2016b).

A tölgyes és a fenyves területeken a legnagyobb arányban a természetközeli élöhelyekhez köthető fajok egyedei voltak jelen, míg a gyepterületek esetében a természetes (klimax) élőhelyekhez köthető fajoké. A bolygatott állapotokat jelző fajok példányai a fenyves, míg a mesterséges állapotokat tolerálóké a tölgyes területekben voltak a legnagyobb arányban jelen. Az erdőkhöz köthető fajok aránya a fenyvesekben, a szegélyekhez köthetőké a tölgyesekben volt a legmagasabb. Mind a nyílt, mind a szárazabb élöhelyeket jelző fajok egyedei a gyepterületeken voltak jelen igen nagy arányban (3. táblázat).

A diverzitás index értékei viszonylag alacsonyak voltak és nagy szórást mutattak $(1,43$ 2,98), a legalacsonyabb értéket a T1, míg a legmagasabbat a R2 területen kaptuk. A kiegyenlítettség értékei átlagosan magasabbak, de szintén jelentős szórás volt tapasztalható köztük $(0,47-0,84)$, a legalacsonyabbat szintén a $T 1$, míg a legmagasabbat szintén a R2 területen kaptuk (3. táblázat). Mindezek oka lehet a tölgyesekben tapasztalt nagy, valamint 
a tisztások esetében tapasztalt alacsony egyedszám, ugyanis az alkalmazott mutatók ezekre az értékre érzékenyek.

3. táblázat: A jelző fajok ökológiai igények (az élőhely természetességi foka, jellege, nyiltsága és humiditása) szerinti százalékos aránya az adott élőhelyen fogott összes egyedszámhoz viszonyítva, valamint a ShannonWeaver indexek és az ekvitabilitás.

Table 3: The rate of the species with ecological preferences (naturalness of the habitats, lightness and humidity) according to the total specimen number in a habitat, and the Shannon-Weaver and the equitability indices.

\begin{tabular}{|c|c|c|c|c|c|c|c|c|}
\hline \multirow{2}{*}{ Mutatók } & \multicolumn{2}{|c|}{ Tölgyes (T) } & \multicolumn{2}{|c|}{ Fenyves (F) } & \multicolumn{2}{|c|}{ Tisztás (R) } & \multirow{2}{*}{ Faj } & \multirow{2}{*}{ Egyed } \\
\cline { 2 - 7 } & $\mathbf{1}$ & $\mathbf{2}$ & $\mathbf{1}$ & $\mathbf{2}$ & $\mathbf{1}$ & $\mathbf{2}$ & & \\
\hline Természetes & 12,73 & 22,38 & 29,26 & 41,53 & 39,73 & 58,68 & 26 & 526 \\
\hline Természetközeli & 75,71 & 53,77 & 45,32 & 40,97 & 24,87 & 17,43 & 24 & 1111 \\
\hline Bolygatott & 1,65 & 1,32 & 15,84 & 7,93 & 3,24 & 12,26 & 6 & 99 \\
\hline Mesterséges & 2,54 & 2,55 & 0,00 & 1,75 & 0,00 & 0,00 & 1 & 34 \\
\hline Erdö & 5,04 & 8,97 & 15,03 & 20,73 & 16,34 & 7,33 & 15 & 210 \\
\hline Szegély & 67,52 & 42,29 & 47,15 & 26,40 & 4,88 & 3,26 & 6 & 903 \\
\hline Nyílt & 5,70 & 7,16 & 6,91 & 19,79 & 51,16 & 64,86 & 28 & 303 \\
\hline Árnyékos & 7,11 & 9,66 & 1,59 & 8,58 & 1,01 & 4,06 & 11 & 147 \\
\hline Száraz & 25,94 & 33,99 & 36,49 & 58,12 & 66,62 & 82,05 & 37 & 805 \\
\hline Humid & 2,13 & 7,69 & 16,66 & 8,85 & 0,00 & 4,34 & 14 & 138 \\
\hline Shannon-Weaverer & 1,43 & 2,02 & 2,12 & 2,53 & 2,79 & 2,98 & & \\
\hline Ekvitabilitás & 0,47 & 0,59 & 0,67 & 0,80 & 0,83 & 0,84 & & \\
\hline & & & & & & & \\
\end{tabular}

A diverzitásrendezés ábráján az egyes területek görbéi viszonylag jól elkülönülnek egymástól, legfölül a tisztások, legallul pedig a tölgyes területeké fut. A görbék, a T2 területet leszámítva, nem metszik egymást. Ez az F1, F2 és R1 területek görbéit metszi (2. ábra). Ezek alapján megállapitható, hogy a legmagasabb diverzitás a tisztások esetében (aminek oka a magas fajszám is lehet), a legalacsonyabb pedig a tölgyesekben tapasztalható, de a T2 terület, valószínüleg az ott csapdázott kimagaslóan nagy egyedszám miatt, ilyen szempontból nem feltétlenül hasonlítható össze a fenyves és tisztás területekkel.

Az ordinációs vizsgálat stressz-függvényének (ST) értéke 0,09 , ami igen közel esik a 0,1-0,2 konfidenciaintervallumhoz (Podani 1997), így relevánsnak tartjuk. A vizsgálat eredménye szerint az egyes élöhelyek jól elkülönülnek egymástól. Az adott élőhelyhez tartozó mintaterületek a tisztások esetében térnek el legjobban, itt az egyes csapdák között is nagyok a különbségek (3. ábra). Mindez szintén magyarázható egyrészt az egyes mintavételi helyek között tapasztalt jelentős egyedszám eltéréssel, valamint minden bizonnyal az élöhelyek eleve eltérő jellegéből adódó különbségekkel is. Míg az erdőállományon belül, az azokhoz köthető fajok viszonylagos könnyedséggel mozoghatnak a számukra kedvező élet- 
terekben és azok között, addig a tisztások egyfajta szigetként viselkednek, így fajösszetételük között kialakulhatnak kisebb-nagyobb különbségek. A fenyves és tölgyes területek közötti eltérés leginkább a jelentősen eltérő egyedszámmal, valamint a fajösszetétel béli különbségekkel magyarázható.

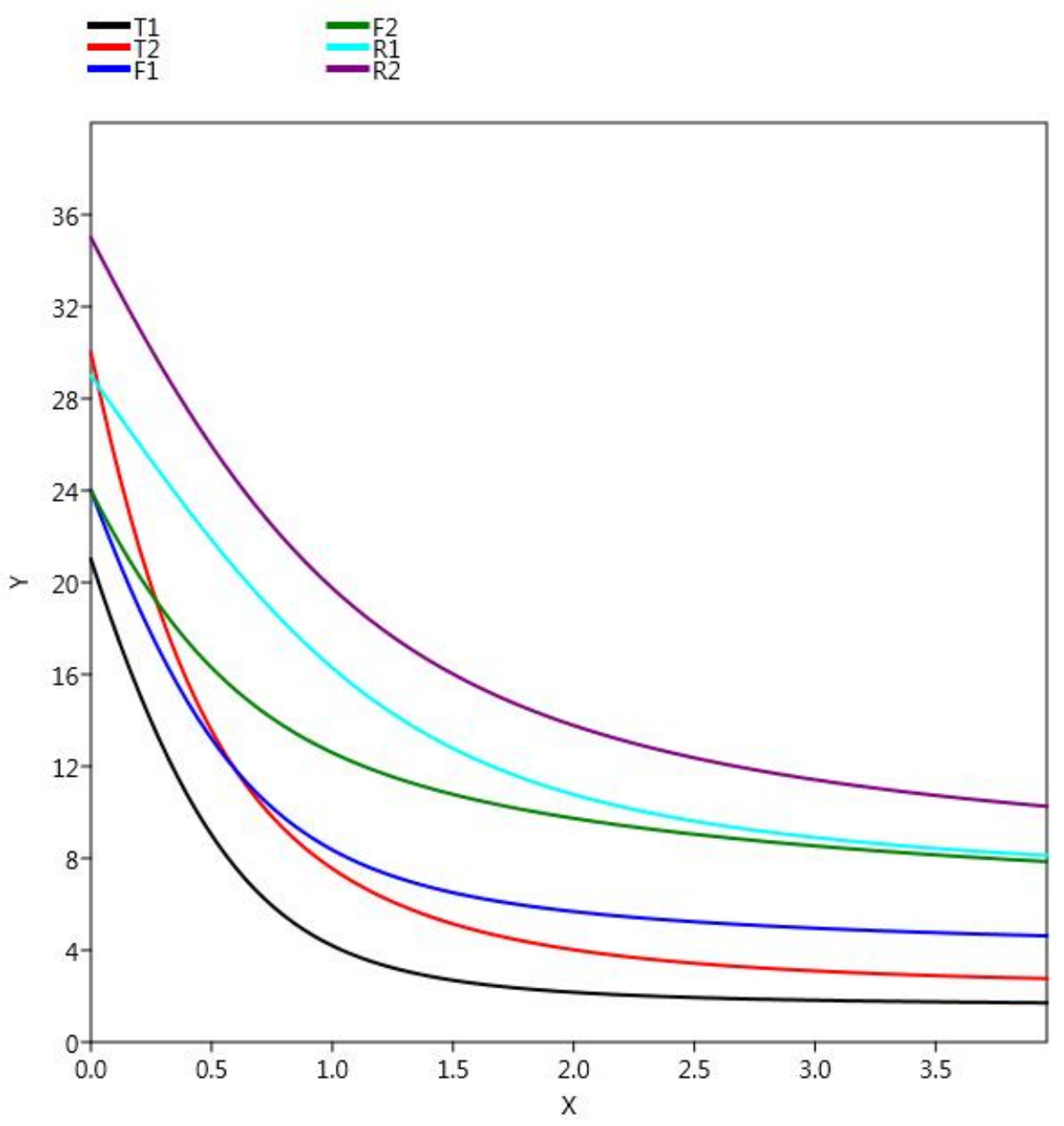

2. ábra: A mintaterületek Rényi-féle diverzitás profiljainak görbéi.

Figure 2: Diversity profiles of the sampling sites.

A Jaccard hasonlósági index alapján elvégzett, és a fajösszetétel-azonosság alapján történt összehasonlítás is hasonló eredményt mutat, mind egymással, mind az előző vizsgálatokkal (4. táblázat). A legnagyobb hasonlóság az egyes mintavételi helyekhez tartozó csapdák között van. Mindkét index szerint leginkább a tisztás-területek térnek el a másik két élöhelytöl. 


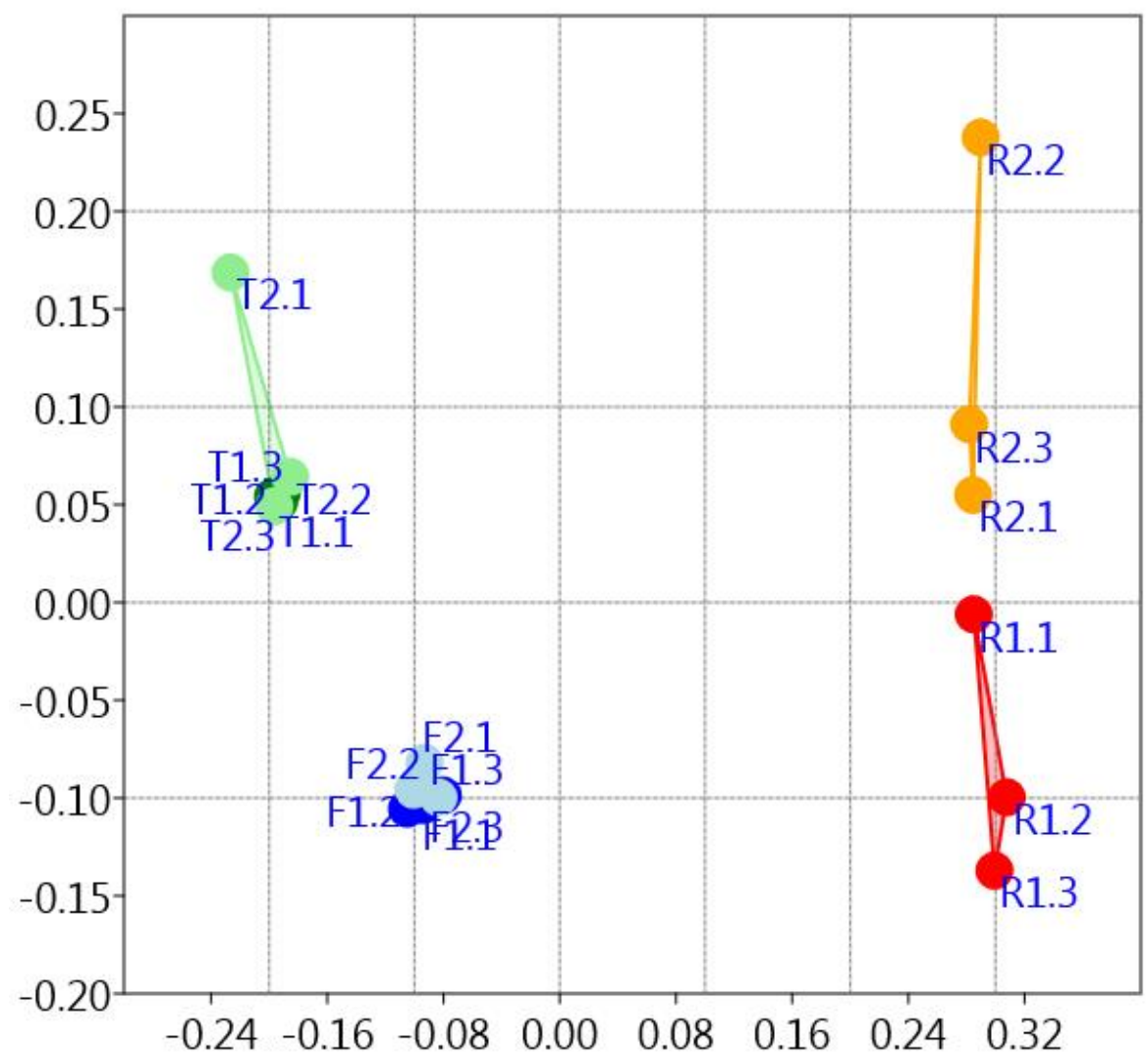

3. ábra: A minden csapdát tartalmazó, Bray-Curtis hasonlósági indexen alapuló ordinációs vizsgálat. Figure 3: Oridinaton, according to the Bray-Curtis similarity index, including every traps.

4. táblázat: A mintaterületek közötti Jaccard-hasonlósági indexek, valamint a fajösszetétel-azonosság (dölt) értékei.

Table 4: Jaccard indices and species composition similarity (italic) values among the survey areas.

\begin{tabular}{|l|c|c|c|c|c|c|c|}
\hline \multirow{2}{*}{ Mintaterületek } & \multicolumn{2}{|c|}{ Tölgyes (T) } & \multicolumn{2}{c|}{ Fenyves (F) } & \multicolumn{2}{c|}{ Tisztás (R) } \\
\cline { 3 - 8 } & & $\mathbf{1}$ & $\mathbf{2}$ & $\mathbf{1}$ & $\mathbf{2}$ & $\mathbf{1}$ & $\mathbf{2}$ \\
\hline \multirow{2}{*}{ Tölgyes (T) } & $\mathbf{1}$ & & 0,42 & 0,36 & 0,45 & 0,25 & 0,22 \\
\cline { 2 - 8 } & $\mathbf{2}$ & 35,40 & & 0,38 & 0,35 & 0,23 & 0,27 \\
\hline \multirow{2}{*}{ Fenyves (F) } & $\mathbf{1}$ & 17,90 & 16,57 & & 0,45 & 0,26 & 0,28 \\
\cline { 2 - 8 } & $\mathbf{2}$ & 20,42 & 16,67 & 32,97 & & 0,36 & 0,28 \\
\hline \multirow{2}{*}{ Tisztás (R) } & $\mathbf{1}$ & 2,81 & 1,94 & 9,60 & 9,42 & & 0,36 \\
\cline { 2 - 8 } & $\mathbf{2}$ & 3,60 & 3,41 & 6,87 & 5,76 & 20,16 & \\
\hline
\end{tabular}




\section{ÖSSZEFOGLALÁS}

Az ásotthalmi Tanulmányi erdő, adataink alapján, az eltérő élőhelytípusok jelenlétnek köszönhetően viszonylag diverz talajfelszíni pókfaunával rendelkezik. A vizsgált élőhelyek egyértelműen elkülönülnek egymástól. A legnagyobb diverzitást a tisztások mutatják, ugyanakkor a legmagasabb egyedszám a tölgyesekben volt tapasztalható. Az erdő természetessége viszonylag jó, bolygatást és mesterséges körülményeket jelző fajok csak alacsony arányban voltak jelen, de a tisztások természetessége egyértelműen magasabb a két fás területénél. A terület általánosan száraznak mondható, de a három vizsgált élőhely közül ilyen tekintetben is kiemelkednek a tisztások, ahol a száraz körülményeket jelző fajok aránya kimagasló, valamint (ehhez kapcsolódóan) a nyiltt területekre jellemző fajok is sokkal gyakoribbak itt, mint az erdőkben.

Vizsgálatunk során több országosan ritka, valamint védett faj is előkerült (Bali et al 2016b). Ezek közül az E. kollari és N. pannonica mindenképpen külön figyelmet érdemelnek, jelenlétükkel növelik a terület természetvédelmi értékét. A két faj populációdinamikájának részletesebb megismerése érdekében érdemesnek tartjuk további, célzott vizsgálatok elvégzését a területen.

\section{KÖSZÖNETNYILVÁNÍTÁS}

Köszönettel tartozunk Andrési Pálnak a csapdák rendszeres üritésében nyújtott segítségeért. Kutatásunkat a TÁMOP-4.2.2B-15/1/KONV-2015-0005 pályázat támogatta.

\section{FELHASZNÁLT IRODALOM}

Andrési D., Kálmán K., Andrésiné Ambrus I. \& Lakatos F. 2015: Adatok az ásotthalmi Tanulmányi erdő futóbogár faunájához (Coleoptera: Carabidae). In: Lipák L. (ed): Alföldi Erdökért Egyesület Kutatói Nap XXIII.: Tudományos eredmények a gyakorlatban, 89-95.

Bali L., Szinetár Cs., Andrési D., Kámpel J. \& Tuba K. 2016a: Mesterségesen kialakított lékek talajközelben élő pókfaunájának (Araneae) vizsgálata. Növényvédelem 52(6): 287-296.

Bali L., Szinetár Cs., Andrési D., Tuba K. \& Kálmán K. 2016b: Ritka és védett pókfajok előfordulása az ásotthalmi tanulmányi erdő területéről In: Lipák L. (ed): Alföldi Erdőkért Egyesület Kutatói Nap XXIV.: Tudományos eredmények a gyakorlatban, 43-48.

Barber H. S. 1931: Traps for cave-inhabiting insects. Journal of the Elisha Mitchell Scientific Society 46: 259266.

Bray J. R. \& Curtis J. T. 1957: An ordination of the upland forest communities of Southern Wisconsin. Ecological Monographs 27: 325-349. DOI: $10.2307 / 1942268$

Buchar J. \& Rǔžička V. 2002: Catalogue of Spiders of the Czech Republic. Peres Publishers, Praha, 17-189. 
Ferris R., Peace A. J. \& Humphrey J. W. 2000: Relationships between vegetation, site type and stand structure in coniferous plantations in Britain. Forest Ecology and Management 136(1-3): 35-51. DOI: $10.1016 /$ s0378$1127(99) 00268-6$

Gallé R. \& Torma A. 2009: Epigeic spider (Araneae) assemblages of natural forest edges in the Kiskunság (Hungary). Community Ecology 10(2): 146-151. DOI: 10.1556/ComEc.10.2009.2.2

Gallé R., Maák I. \& Szpisjak N. 2014: The effects of habitat parameters and forest age on the ground dwelling spiders of lowland poplar forests (Hungary). Journal of Insect Conservation 18(5): 791-799. DOI: 10.1007/s10841-014-9686-9

Gnelista V. A. 2008: A survey of Crimeran Lyniiphidae (Araneae). 1. On seven rare and little known lyniiphids from Crimea. Arthropoda Selecta 17(3-4): 191-202.

Greenstone M. H. 1979: A line transect density index for wolfspiders (Pardosa spp.), and a note on the applicability of catch per unit effort method to entomological studies. Ecological Entomology, 4(1): 23-29. DOI: 10.1111/i.1365-2311.1979.tb00558.x

Halász G. (ed) 2006: Magyarország erdészeti tájai. Állami Erdészeti Szolgálat, Budapest, 154.

Hänggi A., Stöckli E. \& Nentwig W. 1995: Habitas of Central European Spiders. Miscellanea Faunistica Helvetica $4,459$.

Horváth R., Magura T., Szinetár Cs. \& Tóthmérész B. 2009: Spiders are not less diverse in small and isolated grasslands, but less diverse in overgrazed grasslands: A field study (East Hungary, Nyírség). Agriculture Ecosystems \& Environment 130(1-2): 16-22. DOI: 10.1016/j.agee.2008.11.011

Horváth R. 2012: Az urbanizáció hatása erdei talajlakó pókokra. Természetvédelmi közlemények 18: 224-233.

Jaccard P. 1912: The distribution of the flora in the alpine zone. New Phytologist 11: 37-50.

DOI: $10.1111 /$ j.1469-8137.1912.tb05611.x

Kádár F. \& Samu F. 2006: A duplaedényes talajcsapdák használata Magyarországon. Növényvédelem 42(6): 305-312.

Kálmán K. 2016: Futóbogár-együttesek vizsgálata az ásotthalmi Tanulmányi erdőben. Szakdolgozat, Nyugatmagyarországi Egyetem, Erdőmüvelési és Erdővédelmi Intézet, Sopron.

Kiss B. \& Samu F. 2000: Evaluation of population densities of the common wolf spider Pardosa agrestis (Araneae: Lycosidae) in Hungarian alfalfa fields using mark-recapture. European Journal of Entomology 97(2): 191-195.

Loksa I. 1972: Pókok II - Araneae II. Fauna Hungariae 109: 112.

Maelfait J.-P. \& Hendrickx F. 1998: Spiders as bioindicators of anthropogenic stress in natural and semi-natural habitats in Flanders (Belgium): some recent developments. In: Selden P. A. (ed): Proceedings 17th European Colloquium Arachnology, 293-300.

Palmgren P. \& Lönnqvist B. 1974: The spiders of some habitats at the Nåtö Biological Station (Åland, Finland). Commentationes Biologicae 73., Sociezas Scientiarum Fennica, Helsinki, 1-10.

Podani J. 1997: Bevezetés a többváltozós biológiai adatfeltárás rejtelmeibe. Scientia Kiadó, Budapest, 252257.

Renkonen O. 1938. Statisch-ökologische Untersuchungen über die terrestrische Käferwelt der finnischen Bruchmoore. Annales Zoologici Societatis Zoologicae-Botanicae Fennicae 'Vanamo' 6: 1-231.

Rényi A. 1961: On measures of information and entropy. Proceedings of the fourth Berkeley Symposium on Mathematics, Statistics and Probability: Held at the Statistical Laboratory, University of California, June 20July $30,1960,547-561$.

Shannon C. E. \& Weaver W. 1949: The Mathematical Theory of Communication. University of Illinois Press, Urbana and Chicago, 1-117.

Szinetár Cs. 2006: Pókok. Keresztespókok, farkaspókok, ugrópókok és rokonaik a Kárpát-medencében. Élövilág Könyvtár, Kossuth Kiadó, Budapest.

Szinetár Cs., Kovács P., Samu F. \& Horváth R. 2006: Egy kisparcellás lucernaföld talajlakó pókfaunája és annak szezonális változásai a Nyugat-Dunántúlon. A Berzsenyi Dániel Föiskola Tudományos Közleményei XV. Természettudományok, 10: 69-79. 
Szinetár Cs., Erdélyi F. \& Szűts T. 2011: Pókfaunisztikai vizsgálatok a nagykőrösi pusztai tölgyesek területén. In: Verö Gy. (ed): Természetvédelem és kutatás a Duna-Tisza közi homokhátságon - Tanulmánygyüjtemény. Rosalia 6. Duna-Ipoly Nemzeti Park Igazgatóság, Budapest, 209-221.

Wise D. 1993: Spiders in Ecological Webs (Cambridge Studies in Ecology). Cambridge University Press, Cambridge, 1-289. DOI: 10.1017/CBO9780511623431

Woodcock B. A. 2005: Pitfall trapping in ecological studies. In: Leather S. (ed): Insect Sampling in Forest Ecosystems. Blackwell, Oxford, 37-57. DOI: 10.1002/9780470750513.ch3

100/2012. (IX. 28.) VM rendelet - A védett és a fokozottan védett növény- és állatfajokról, a fokozottan védett barlangok köréröl, valamint az Európai Közösségben természetvédelmi szempontból jelentős növény- és állatfajok közzétételéről szóló 13/2001. (V. 9.) KöM rendelet és a növényvédelmi tevékenységről szóló 43/2010. (IV. 23.) FVM rendelet módositásáról.

http://www.kozlonyok.hu/nkonline/MKPDF/hiteles/mk12128.pdf (2017. május).

Érkezett: 2017. március 31.

Közlésre elfogadva: 2017. május 23. 